\title{
Assessment of the Energy Savings Potential in the Residential Building Stock in Bosnia and Herzegovina
}

\author{
Nermina Zagora*, Mladen Burazor, Erdin Salihović \\ Faculty of Architecture, University of Sarajevo, Bosnia and Herzegovina
}

\author{
Citation: Zagora N, Mladen Burazor M, Salihović E. \\ Citation: Zagora N, Mladen Burazor M, Salihovic $\mathrm{E}$.
Assessment of the Energy Savings Potential in the \\ Assessment of the Energy Savings Potential in the
Residential Building Stock in Bosnia and Herzegovina. \\ Residential Building Stock in Bosnia and Herzegovina.
SEE J Archit Des. 2017 Nov 21; 2017:10029. \\ hEE J Archit Des. 2017 Nov 21; \\ Keywords: building typology; residential buildings: \\ Keywords: building typology; residential b
energy efficiency; energy savings; EE measures. \\ Correspondence: Nermina Zagora. Faculty of \\ Architecture, University of Sarajevo, Sarajevo, Bosnia and \\ Architecture, University of Sarajevo, Sarajevo \\ Received: 16-Mar-2017; Revised: 19-Apr-2017; \\ Accepted: 20-Apr-2017; Published: 21-Nov-2017 \\ Copyright: ๑ 2017 Nermina Zagora, Mladen Burazor \\ Erdin Salihović. This is an open-access article distributed \\ under the terms of the Creative Commons Attribution \\ Funding: This research did not receive any financia \\ Competing Interests: The author has declared that no \\ competing interests exist.
}

This paper intends to bring attention of both scientific and general audience to the status quo of the existing residential building stock in Bosnia and Herzegovina, highlighting its energy savings potential. The research results presented in this text may be applicable on two levels: on a larger scale, the policy makers may use this data in the process of development of strategic and EE measures implementation plans, while, on a smaller scale, the individua users may gain practical insight into the benefits of energy saving measures and implement them in their own households. Moreover, the exposed data may be subject to further evaluations, studies and comparisons, while the presented methodology can be used by other researchers in countries where there have not been research activities on the existing residential buildings stock from the EE perspective.

\section{Introduction}

Energy efficiency policies and initiatives have already gained common acceptance and delivered positive outcomes in the developed countries of the world. The reasons to pursue energy efficiency have become widely accepted in a contemporary world, where there is a constant demand for more energy, while at the same time the quality of air, water and soil is continuously deteriorating as a result of demands to produce energy. Environmental changes are evident, and on the global scale we can see joined efforts to combat the climate change. The 2016 Paris agreement not only deals with the global temperature rise but also with strengthening of the countries' capacities to deal with the impacts of climate change. In order to achieve the defined goals, the plan is to establish "appropriate financial flows, a new technology framework and an enhanced capacity building framework", and, at the same time, to support the actions in line with the countries' own national objectives [1].

Although Bosnia and Herzegovina is still not a part of the European Union, the legislative reforms in many spheres are often informed by the EU regulations and by adopting positive European practices. In this regard, the $\mathrm{FBiH}$ Energy Efficiency (EE) Law, passed in February 2017, has embraced the three EU directives: 2006/32/EZ, 2010/31/EZ, 2010/30/EU [2, 3].

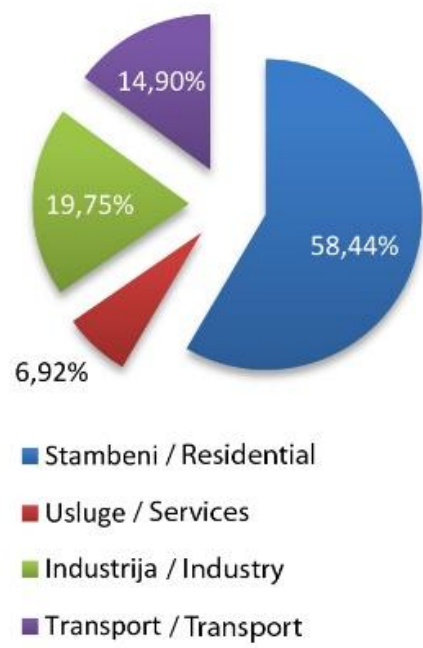

Figure 1: An estimation of the total energy use in Bosnia and Herzegovina, 2010 (NEEAP, February, 2012 p. 13) 
In order to establish the baseline parameters for further recommendations, it is valuable to assess the share of the total energy use by the residential sector in $\mathrm{BiH}$ [3] in comparison to the European standards. According to the NEEAP (NEEAP = National Energy Efficiency Action Plan of Bosnia and Herzegovina) estimate, the residential sector in $\mathrm{BiH}$ is the largest consuming sector, with a share of more than $50 \%$ of energy use [4], which is more than $30 \%$ higher than the average share in the EU countries [5] (Figure 1, Figure 2).

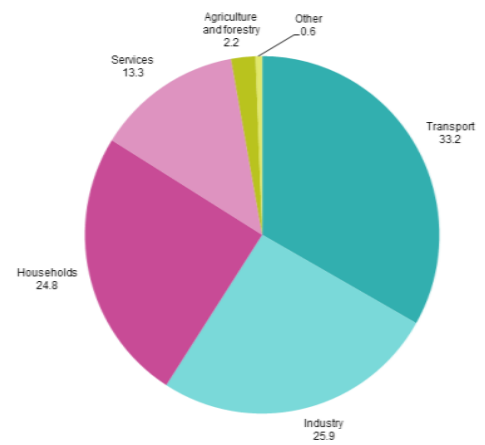

Figure 2: Final energy consumption, EU-28, 2014 (EUROSTAT, 2014) [5]

The IEA data for 2013 [6] ("IEA aggregate refers to the twenty IEA member countries for which energy efficiency data covering most of the end users are available: Australia, Austria, Belgium, Canada, Czech Republic, Finland, France, Germany, Greece, Ireland, Italy, Japan, Korea, New Zealand, The Netherlands, Spain, Sweden, Switzerland, the United Kingdom and the United States. These countries represented $85 \%$ of the total 2013 IEA final energy consumption."), which indicate that the residential sector in the IEA countries accounted for the $21 \%$ share of final energy consumption, further underscore the unfavourable EE indicators of the residential building stock in $\mathrm{BiH}$ [7] (Figure 3).

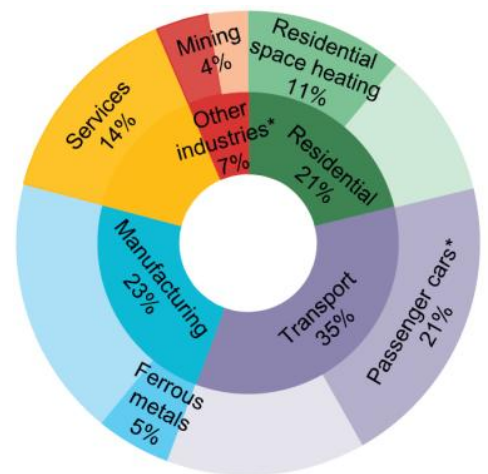

Figure 3: Total energy use for IEA member countries, 2013 (International Energy Agency, 2016: p. 6) [5]

The above analysis clearly indicates the necessity to focus the research towards the impact of the residential sector in Bosnia and Herzegovina on the overall energy consumption in Bosnia and Herzegovina. Some of the most significant indicators of the low level of energy efficiency awareness can generally be attributed to the basic technical issues, such as the lack of or the poor thermal insulation of the architectural envelope, the deteriorated condition of windows and the technologically outdated heating systems. Over $85 \%$ of dwelling units in $\mathrm{BiH}$ are characterized by an extremely poor energy performance with a high coefficient of heat transfer of external heat layer $(U)$, resulting in the inefficient enduse of an estimated $30 \%$ of energy loss (World Bank, 2012 p. 138) [8]. According to the European classification EMAS [9], an average residential building in $\mathrm{BiH}$ can be associated with the " $\mathrm{F}$ " energy class (161-200 kWh/m²) (CETEOR Sarajevo, 2012) [10]. According to the statistical data, the average size of a dwelling unit $\mathrm{BiH}$ is cca $77,07 \mathrm{~m}^{2}$ (Agency for Statisics of Bosnia and Herzegovina, 2016 p. 222) [11], yet, only the $59.60 \%$ of the residential space is heated (Agency for Statistics of Bosnia and Herzegovina, 2015 p. 9) [12].

In order to address the identified issues related to the low level of energy efficiency in the residential sector in $\mathrm{BiH}$, a research project entitled "Typology of residential buildings in Bosnia and Herzegovina" (Arnautović-Aksić, et al., 2016) was conducted from 2014 to 2016 [13]. Based on the data collected from the research, this paper intends to specifically focus on the topic of energy savings, targeting the segments of the residential stock in Bosnia and Herzegovina that possess the highest potential for the EE.

\section{Methodology of the research project "Typology of residential buildings in Bosnia and Herzegovina"}

The research project "Typology of residential buildings in Bosnia and Herzegovina" emerged from the basic methodological framework of the European research project Tabula ((IWU), 2017) [14], which was harmonised with the directives 2002/91/EC and 2006/32/EC and co-financed by the European Commission's IEE programme. The Tabula project was essentially conceived as a unique typological model of classification of residential buildings according to their construction period, as well as their physical and architectural properties. After the Tabula project was implemented in 20 European countries, a team of experts in architectural and mechanical engineering from Bosnia and Herzegovina, in collaboration with GIZ (GIZ, abbrev. German Agency for International Cooperation (Deutsche Gesellschaft für Internationale Zusammenarbeit (GIZ) $\mathrm{GmbH}$, germ.), conducted an elaborate research of the residential stock at the national level. The research 
was based on the Tabula project methodology and it included the statistical survey of 13,044 existing residential buildings in $\mathrm{BiH}$, as well as the classification of the surveyed buildings according to the predefined criteria, by means of applying the historical, inductivedeductive and comparative scientific methods. The collected registry of data on the residential stock at the level of Bosnia and Herzegovina offered numerous possibilities for statistical analysis, and, among others, a cluster analysis, which facilitated the selection of 29 representative buildings for each of the residential typological categories. The final selection of the representative buildings or the so-called "typical buildings", as the real representatives amongst the entire statistical sample, was as a result of the exploration of the average characteristics of each individual category.

Typical residential buildings in $\mathrm{BiH}$ are displayed in the typological matrix, organized in two categories of single-family and four categories of collective housing, by columns, as well as in six categories according to their construction periods, by rows (Error! Reference source not found.4).

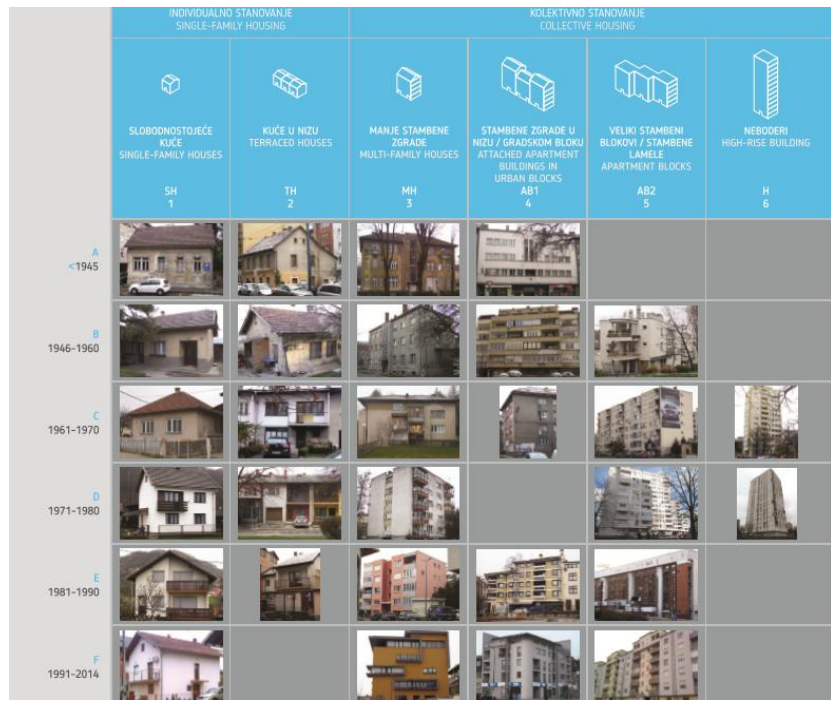

Figure 4: The matrix of typical residential buildings in Bosnia and Herzegovina

After the residential typology matrix was created, the research continued in the top down approach: each of the typical buildings, located throughout $\mathrm{BiH}$, was documented in the course of the field work, and the collected data was used for the calculation of energy performance of individual buildings. Finally, the detailed architectural and thermo-technical data for each typical building, from its present state of energy performance to the potential energy savings after the application of two levels of $E E$ improvements are included in the book.

As the applied methodology embraced the top down and bottom up approaches, the research results were projected both at the level of the individual buildings as well as at the national level. Therefore, the applicative value of the research on the typology of residential buildings in Bosnia and Herzegovina may be regarded from several perspectives. The obtained data may be simultaneously used on a large and on a small scale, and may involve several stakeholders: from the governmental and non-governmental institutions and funds, to the financing institutions, the commercial companies and construction industries, the engineers and, finally to the end users. On the one hand, interpretation of the data on a larger scale may be beneficial to the governmental, financial and industrial sectors in identifying targets in the implementation of EE planning schemes in residential sector, as well as in developing further research. On the other hand, the end-users may learn about the benefits of refurbishment of the building types they inhabit, thus contributing to raising awareness of the general public.

For all of the named reasons, this paper comprises of an interpretation of the research results on a larger scale, highlighting the absolute energy saving potential at the level of the entire residential stock in Bosnia and Herzegovina, as well as on a smaller scale, indicating the benefits of the EE measures application - at the level of individual buildings and its end-users.

\section{Analysis of the absolute energy savings potential at the level of the residential stock in Bosnia and Herzegovina}

One of the most valuable results of the research on the typology of residential buildings in Bosnia and Herzegovina (Arnautović-Aksić, et al., 2016 [13], is the quantitative overview of the energy required for the heating of all residential building types, which also shows the potential effects of the implementation of EE measures improvement (Error! Reference source not found.).

Table 1: Energy consumption and energy saving measures (Source: Authors, 2017)

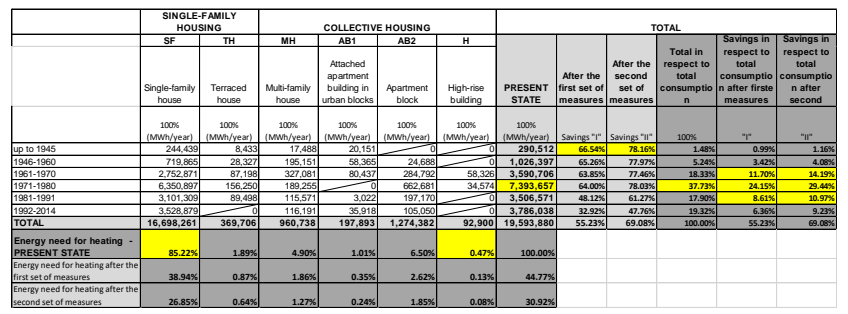

According to calculations based on the statistical data, the highest share of energy consumption is accounted to the typology of singlefamily houses $(85.22 \%)$, whereas the lowest share is 
in high-rise residential buildings (0.47\%). Such a distribution of consumption values was not surprising, as it is related to the volume of typologies within the overall distribution of the building stock; single-family houses represent the largest, while high-rise buildings are the smallest typology group.

When observing energy consumption values of buildings arranged by their construction periods, the largest value of $37.73 \%$ of the total energy need for the entire residential building stock is attributed to the buildings constructed in the period from 1971 to 1980 . In terms of EE measures planning on the level of Bosnia and Herzegovina, the highlighted energy consumption value indicates that buildings from that period should be regarded as priority for refurbishment. On the other hand, the development of the EE strategies at the local levels of government in $\mathrm{BiH}$ (cantons and municipalities) requires a particular and adapted approach. The reason is that the structure of the building stock varies from one settlement to another, in terms of building age and quantitative distribution of buildings types. This implies the necessity for the local levels of government to keep the track of the present state of building stock within their administrative borders, in order to create their own typology matrices and proceed to creating their particular action plans.

The overall results of the research can be interpreted in two ways: on a larger scale, focusing on the absolute effects of the efficiency improvement measures, as well as on the smaller scale, assessing its relative effects. The absolute effects indicate the quantitative impact of improvements of the overall energy demand for heating at the level of the entire residential stock, while the relative effects address the typical buildings and indicate the measurement of improvements in comparison to its baseline. The calculation of the effects of EE improvements was conducted on the basis of two predefined levels of efficiency measures: the basic level, consisting of the standard measures of improvement the characteristics of architectural envelope, and the advanced level, consisting of the non-standard measures, which may significantly improve the energy/building class.

Implementation of either one of the level of improvement measures have the most significant relative impact on all buildings types constructed before 1945, with a potential reduction of their energy demand up to $66.54 \%$ by the standard improvement measures, and to the $78.16 \%$ the non-standard improvement measures. However, the largest absolute impact on energy demand lies in potential implementation of the standard and non-standard efficiency measures of the buildings dating from the period from 1971 to 1981 , with a possible decrease of energy consumption by $24.15 \%$ and $29.44 \%$, respectively. Refurbishment of all buildings constructed from 1961 to 1991 would contribute to $44.46 \%$ of overall energy savings with standard measures, and $54.60 \%$ with non-standard measures.
The highlighted values indicate the potential energy savings in specific segments of residential stock and may be relevant for the policy makers in enacting $E E$ actions plans.

The most favourable absolute effects of the $21.02 \%$ decrease in energy demand of the entire residential building stock can be attained by standard measures in single-family houses from the 1971-1980 period, and subsequently, in apartment blocks typology $(2.03 \%)$, dating back from the same period. Furthermore, the refurbishment of multi-family houses built from 1961 to 1970 may result with $1.07 \%$ reduction of total energy demand, followed by terraced houses from 1971-1980 (0.36\%) and attached apartment buildings in urban blocks from 1961-1970 $(0.29 \%)$. Implementation of standard EE measures on high-rise buildings from 1961 to 1970 may contribute to $0.22 \%$ of the reduction of total building stock energy demand.

Table 2: Relative and absolute energy savings values

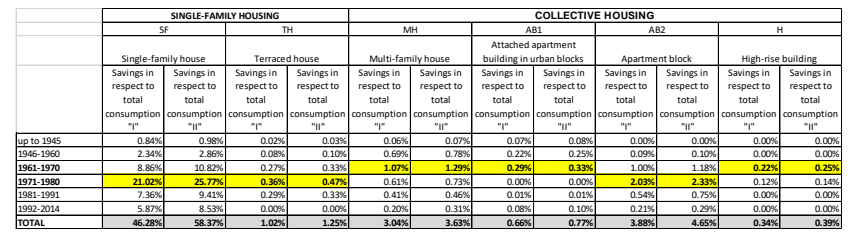

Another relevant aspect of analysis is the comparison between the single-family and collective housing. Energy savings potential in single housing may have absolute effects of $47.30 \%$ compared to $7.93 \%$, which may be achieved in collective housing by implementing standard EE measures. In case of implementing the non-standard measures, the saving values raise to $59.69 \%$ and $9.45 \%$, in single-family and collective housing, respectively. Consequently, EE investments in the segment of single-family housing are likely to produce the best results and deserve to be placed in the focus of financial and legislative plans.

\section{Analysis of the relative energy savings potential at the level of typical buildings}

Apart from its applicative potential on a larger scale - at the policy making level on the residential sector energy efficiency improvements, the results of the research on residential buildings typology may be beneficial to the general public in Bosnia and Herzegovina. The typology matrix (Figure 4) was envisaged as a simple tool that may be beneficial for the end-users to identify the type of building they inhabit. By providing data on the average architectural, physical and thermo-technical properties of the typical buildings and by providing an insight to the end-users in the benefits of application of energy efficiency 
measures, one of the objectives of the project "Typology of residential buildings in $\mathrm{BiH}$ " was to raise awareness on energy efficiency in the residential sector.

In order to perform energy audits for the 29 typical buildings, the methodology of in situ research included the study of the original project documentation, detailed measurements as well as the collection of relevant data for all the typical buildings located throughout the territory of Bosnia and Herzegovina. The calculation of values of the specific energy needs (Table 3 ) for heating was conducted in accordance with the valid regulations in both entities and the standard BAS EN ISO 13790. The energy demand calculation for heating per square metre of typical residential buildings was required in order to calculate the total amount of annual energy demand for the entire residential sector, on the one hand, while, on the other hand, it serves for the end-users to learn about the potential reduction of energy consumption after application of the proposed EE measures.

Table 3: Overview of the values of the specific energy need for heating for 29 typical residential buildings in Bosnia and Herzegovina

\begin{tabular}{|c|c|c|c|c|c|c|}
\hline \multicolumn{7}{|c|}{\begin{tabular}{l|l|l|l} 
PRESENT STATE & \\
\end{tabular}} \\
\hline \multicolumn{7}{|c|}{ Specific energy need for intermitted heating QH,nd,interm ( $\mathrm{kWh} / \mathrm{m} 2 /$ year) } \\
\hline & SINGLE-FAMILY HO & USING & COLLECTIVE HC & OUSING & & \\
\hline & SH & $\mathrm{TH}$ & $\mathrm{MH}$ & $\mathrm{AB1}$ & AB2 & $\mathrm{H}$ \\
\hline & $\begin{array}{l}\text { Single-family } \\
\text { house }\end{array}$ & $\begin{array}{l}\text { Terraced } \\
\text { house }\end{array}$ & $\begin{array}{c}\text { Multi-family } \\
\text { house }\end{array}$ & $\begin{array}{c}\text { Attached } \\
\text { apartment building } \\
\text { in urban blocks }\end{array}$ & $\begin{array}{c}\text { Apartment } \\
\text { block }\end{array}$ & $\begin{array}{l}\text { High-rise } \\
\text { building }\end{array}$ \\
\hline up to 1945 & 452.34 & 183.16 & 230.73 & 176.08 & & \\
\hline $1946-1960$ & 473.96 & 321.27 & 216.19 & 158.75 & 176.71 & \\
\hline $1961-1970$ & 464.90 & 196.42 & 188.44 & 153.05 & 170.10 & 193.37 \\
\hline $1971-1980$ & 381.59 & 199.04 & 146.79 & & 129.85 & 125.64 \\
\hline 1981-1991 & 135.93 & 219.20 & 189.20 & 93.62 & 110.87 & \\
\hline $1992-2014$ & 127.61 & & 65.22 & 68.06 & 54.81 & \\
\hline
\end{tabular}

Analysis of the reduction of values of energy demand after the application of the standard EE measures shows that the relative effects which can be attained in the single-family housing typologies on average account for $55.71 \%$, in the collective housing typologies the average reduction is $69.02 \%$.

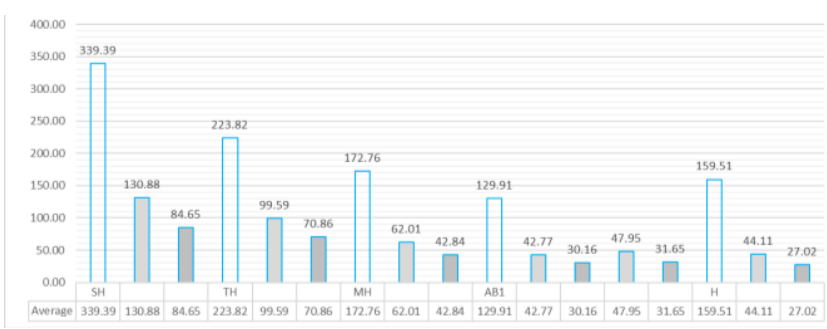

Figure 5: Average values of reduction of the of energy need after application of the EE measures

A presentation of estimates of the potential reduction of energy demand for each residential building type is intended to encourage future investments by end-users, and by undertaking small steps to influence the overall energy efficiency progress in the residential sector.
Nevertheless, experiences of countries with a longer tradition in developing energy efficiency strategies indicate that the pursuit of the defined objectives in the context of Bosnia and Herzegovina will surely be characterised by many obstacles:

"Numerous barriers are responsible for this persistent energy efficiency gap. Market barriers include, for example, difficulty in accessing capital, the presence of information asymmetries, and principalagent problems, also referred to as split incentives. Financial barriers are also decisive in inhibiting progress towards more energy efficient buildings. Such barriers encapsulate a wide range of issues, including the initial cost barrier, risk exposure, discount factor issues, and the inadequacy of traditional financing mechanisms for energy efficiency projects." (IEA/ OECD, 2008) [15].

In conclusion, this paper emphasized the energy savings potential of the residential sector as one of the key priorities in energy efficiency strategies in Bosnia and Herzegovina. The research results, indicating the benefits of EE measures implementation in the residential sector should be addressed to all stakeholders simultaneously, both on the large and the small scale - starting from the top, state-level, to the local levels of policy making, and, finally may involve individual end-users.

The quantitative analyses presented in this paper show that the most significant energy saving potential at the level of Bosnia and Herzegovina lies in the single-family housing residential typologies. In comparison to the energy saving potential of $7.93 \%$ in collective housing, the implementation of EE measures in single-family housing may result with the absolute savings of $47.30 \%$. Detailed analyses of the building types by their age demonstrate that the most favourable absolute effects of $21.02 \%$ of decrease in energy demand of the entire residential building stock can be attained by standard measures in single-family houses from the 1971-1980 period, and, subsequently, in apartment blocks typology (2.03\%), dating back from the same period. When it comes to looking at the relative effects of energy saving strategies, the potential reduction that can be attained in the singlefamily housing typologies on average accounts for $55.71 \%$, while, in the collective housing typologies, the average reduction is $69.02 \%$.

The presented data should serve governmental, financial and industrial sectors in identifying targets in the implementation of $E E$ planning schemes in the residential sector, as well as in developing further research in order to devise action plans and implementation schemes. Moreover, in order to attain the effects of the EE measures implementation, the local authorities may perform individualized research of the building stock within each municipality, applying the same methodology that was used on the level of Bosnia and Herzegovina. Last but not least, the end-users may learn about the 
benefits of refurbishment of the building types they inhabit, thus contributing to raising awareness of the general public, by applying the EE measures in their own capacity.

\section{References}

1. United Nations Framework Convention on Climate Change, 2016.

2. FBiH Energy Efficiency (EE) Law, February 2017.

3. Ministarstvo vanjske trgovine i ekonomskih odnosa Bosne Hercegovine. IZVJEŠTAJ O STANJU OKOLIŠA U BOSNI I HERCEGOVINI, 2012.

4. Union E. Directive 2009/28/EC of the European Parliament and of the Council of 23 April 2009 on the promotion of the use of energy from renewable sources and amending and subsequently repealing Directives 2001/77/EC and 2003/30/EC. Official Journal of the European Union. 2009;5:2009.

5. International Energy Agency. Energy efficiency indicators. OECD/IEA. s.I. : IEA Publications, 2016.

6. Karakosta C, Flouri M, Dimopoulou S, Psarras J. Analysis of renewable energy progress in the western Balkan countries: Bosnia-Herzegovina and Serbia. Renewable and Sustainable Energy Reviews. 2012;16(7):5166-75. https://doi.org/10.1016/i.rser.2012.04.040

7. International Energy Agency. Key world energy statistics.
International Energy Agency, 2007

8. World Bank. Bosna i Hercegovina: Izazovi i preporuke za reforme, Pregled javnih rashoda i institucija. 2012.

9. United Nations Framework Convention on Climate Change. United Nations Framework Convention on Climate Change. The Paris Agreement. [Online] 28 November 2016. http://unfccc.int/paris_agreement/items/9485.php

10. CETEOR Sarajevo. ENERGETSKA EFIKASNOST U BiH. Sarajevo, Bosnia and Herzegovina : s.n. Savremeni pristup energetskoj efikasnosti u arhitekturi i građevinarstvu - Simpozij, 03 February 2012.

11. Agency for Statisics of Bosnia and Herzegovina. CENZUS OF POPULATION, HOUSEHOLDS AND DWELLINGS IN BOSNIA AND HERZEGOVINA, 2013. s.l.: Agency for Statistics of Bosnia and Herzegovina, 2016.

12. Agency for Statistics of Bosnia and Herzegovina. SURVEY ON HOUSEHOLOD ENERGY CONSUMPION. Sarajevo: Agencija za statistiku Bosne i Hercegovine, 2015.

13. Arnautović-Aksić, Dragica, et al. Typology of residential buildings in Bosnia and Herzegovina. [ed.] Dragica Arnautović-Aksic and Nermina Zagora. Sarajevo: Faculty of Architecture, University of Sarajevo, 2016.

14. (IWU), Institut Wohnen und Umwelt GmbH. 2017. TABULA [Online] 2017. http://episcope.eu/iee-project/tabula/.

15. IEA / OECD. Promoting energy effieciency investments: Case study in the residential sector. Paris : International Energy Agency, 2008. 